\title{
TINGKAT DEPRESI LANSIA YANG TINGGAL DI PANTI SOSIAL
}

\author{
Putu Eka Novayanti ${ }^{*}$, Mateus Sakundarno Adi $^{2}$, Rita Hadi Widyastuti ${ }^{1}$ \\ ${ }^{1}$ Program Studi Magister Keperawatan, Universitas Diponegoro, J1. Prof. Soedarto, Tembalang, Kec. Tembalang, Kota \\ Semarang, Jawa Tengah, Indonesia 50275 \\ ${ }^{2}$ Fakultas Kesehatan Masyarakat, Universitas Diponegoro, J1. Prof. Soedarto, Tembalang, Kec. Tembalang, Kota \\ Semarang, Jawa Tengah, Indonesia 50275 \\ *nova_yanti11@yahoo.co.id
}

\begin{abstract}
ABSTRAK
Menua merupakan suatu keadaan yang pasti dirasakan oleh setiap individu, namun menua dengan sehat belum tentu dirasakan oleh setiap lansia. Salah satu masalah psikologis yang paling banyak terjadi pada lansia ialah depresi. Depresi pada lansia sering sekali tertutupi oleh gejala fisik. Depresi dipengaruhi oleh beberapa faktor diantaranya biologi, psikologis dan sosial. Angka kejadian depresi yang terus meningkat dikhawatirkan akan berdampak pada penurunan kualitas kesehatan serta kualitas hidup lansia. Tujuan penelitian ini adalah untuk mengetahui tingkat depresi lansia yang tinggal di panti sosial. Penelitian ini merupakan suatu studi dengan desain cross sectional. Observasi dilakukan terhadap 135 lansia yang didapatkan melalui teknik purpossive sampling dan dilakukan pada bulan Maret 2020. Kriteria inklusi penentuan sampel adalah lansia yang berusia 60 tahun keatas, lansia yang telah menghuni panti selama lebih dari 6 bulan dan tidak memiliki keluarga. Hasil penelitian didapatkan bahwa lansia yang tinggal di panti sosial terbanyak pada rentang usia 65-69 tahun (37,0\%), rentang usia lansia yang paling sedikit adalah lansia yang berusia 80 tahun keatas $(10,4 \%)$. Jenis kelamin lansia yang paling banyang tinggal di panti sosial adalah laki-laki yaitu sebanyak 73 lansia $(54,1 \%)$. Data karakteristik pendidikan lansia yang tinggal di panti sosial paling banyak adalah SD sebanyak 50 lansia (37,0\%). Status pernikahan lansia yang ada di panti sosial terbanyak adalah duda yaitu sebanyak 65 lansia $(48,1 \%)$. Tingkat depresi pada lansia yang ada di panti sosial terbanyak adalah tingkat depresi ringan yaitu sebanyak 55 lansia $(40,7 \%)$
\end{abstract}

Kata kunci: depresi, lansia, panti sosial

\section{THE LEVEL OF DEPRESSION IN THE ELDERLY LIVING IN NURSING HOME}

\begin{abstract}
Aging is a condition that must be felt by every individual, but aging is not necessarily healthy for every elderly. One of the most common psychological problems in the elderly is depression. Depression in the elderly is often masked by physical symptoms. Depression is influenced by several factors including biology, psychological and social. It is faered that the incidence of depression will increase the quality of health and the elderly quality of life. The aim of this study is to determine the level of depression in the elderly who live in nursing homes. Ths research is a study with cross sectional design. The observations were made on 135 elderly who were obtained through purposive sampling techniques and carried out in March 2020. The inclusion criteria for determining the sample are the elderly who are aged 60 years and over, the elderly who have inhabited in nursing home for more than 6 months and have no family. The result showed that the most elderly people living in nursing home were in the age range of 65-69 years (37,0\%), the lowest age range was the elderly who were aged 80 years and over $(10,4 \%)$. The most eldely sexes who live in nursing home are male, as many as 73 elderly people $(54,1 \%)$. Data on the characteristics of the education of the elderly who live in nursing home is the most elementary school as many as 50 elderly $(37,0 \%)$. The status of the marriage of the elderly in the most nursing home is widower with 65 elderly people $(48,1 \%)$. The highest level of depression in elderly at nursing home is the level of mild depression, which is 66 elderly $(40,7 \%)$.
\end{abstract}

Keywords: depression, elderly, nursing home

\section{PENDAHULUAN}

Populasi lanjut usia atau yang sering disebut lansia tersebar di semua daerah dan negara di dunia (Mahendra Dwi Darmawan, 2016). Di Indonesia peningkatan Usia Harapan Hidup akan menyebabkan meningkatnya jumlah lanjut usia.
Berdasarkan data proyeksi penduduk, diperkirakan peningkatan jumlah lansia pada tahun 2025 (33,69 juta), tahun 2030 (40,95 juta) dan tahun 2035 (48,19 juta) (Kemenkes RI, 2018).

Besarnya jumlah penduduk lansia di Indonesia membawa dampak yang positif dan negatif. 
Dampak positif akan timbul apabila penduduk dalam keadaan sehat, produktif dan aktif. Namun, besarnya jumlah penduduk lansia menjadi beban jika lansia memiliki masalah penurunan kesehatan yang berakibat pada peningkatan biaya pelayanan kesehatan, penurunan pendapatan atau penghasilan, peningkatan disabilitas, tidak berdaya, tidak adanya dukungan sosial dan lingkungan yang tidak ramah terhadap penduduk lansia (Sari, 2012). Masalah lain yang akan muncul akibat dari peningkatan jumlah penduduk lansia adalah munculnya masalah kesehatan lansia baik fisik maupun psikososial seperti depresi (Anik Supriani, 2011).

Depresi pada lansia adalah suatu masa terganggunya fungsi dalam diri manusia yang berkaitan dengan alam perasaan yang sedih serta gejala yang menyertainya. Definisi lain dari depresi adalah gangguan perasaan hati dengan ciri sedih merasa sendirian, rendah diri, putus asa, biasanya disertai tanda-tanda retardasi psikomotor atau kadang-kadang agitasi, menarik diri dan terdapat gangguan begetatif seperti insomnia dan anoreksia (JA, 2010). Lansia yang memiliki potensi terkena depresi paling tinggi adalah lansia yang tinggal di panti dibandingkan dengan lansia yang tinggal dirumah dengan keluarga atau yang sedang mendapatkan perawatan di rumah sakit (Pae, 2017). Hal ini dikarekan, lansia yang berada di panti tinggal terpisah jauh dari keluarga sehingga tidak memiliki tempat untuk berbagi masalah dan kesedihan yang dirasakan. Depresi pada lansia lebih sulit untuk dideteksi dikarenakan usia lanjut yang sering menutupi kesepian serta rasa sedih dengan justru lebih aktif dalam mengikuti kegiatan (Livana PH, Yulia S, 2019).

Depresi dilatarbelakangi oleh berbagai permasalah kehidupan yang dihadapi oleh setiap individu. Fator-faktor depresi pada lansia yang berkaitan dengan faktor sosiodemografik adalah usia, jenis kelamin, tingkat pendidikan, pekerjaan, tingkat penghasilan dan status pernikahan. Model regresi univariat yang dilakukan mengemukakan bahwa faktor usia, jenis kelamin wanita, tingkat pendidikan rendah, gangguan kognitif dan tidak memiliki pasangan hidup dapat meningkatkan risiko menderita depresi (Azizah., 2011). Sementara itu, penelitian lain menambahkan bahwa lansia yang menderita penyakit jantung koroner, gangguan fungsional dan peristiwa kehidupan penuh tekanan atau stres juga dapat meningkatkan risiko terkena depresi (Suardiman, 2011).
Berdasarkan hasil studi pendahuluan yang dilakukan didapatkan 135 lansia (laki-laki 73 orang dan perempuan 62) yang tinggal di Panti Sosial, kebanyakan dari lansia tersebut adalah lansia yang tidak memiliki anggota keluarga. Kesepian akan sangat dirasakan oleh lansia yang hidup sendirian, tanpa anak, kondisi kesehatannya yang rendah, tingkat pendidikannya rendah dan rasa percaya diri rendah, dari beberapa penyebab tersebut bisa timbul depresi. Kondisi seperti ini seharusnya tidak dialami oleh lansia. Usia lanjut semestinya menjadikan sisa hidup lansia lebih bahagia dengan ditemani oleh keluarga, menikmati hasil jerih payah yang selama hidup telah dicapai dan mendekatkan diri kepada Sang Pencipta (Pae, 2017). Masih banyak kejadian dilapangan yang mengharuskan lansia untuk tinggal di panti sosial dan terpisah jauh dari keluarga. Berdasarkan hasil wawancara yang dilakukan dengan 10 orang lansia, 5 diantaranya mengatakan tidak bersemangat, duduk menyendiri, dan merasakan kesepian. Hasil wawancara pada 5 lansia lainnya didapatkan bahwa selama tinggal di Panti Sosial lansia tidak pernah didatangi oleh keluarga. Berdasarkan uraian tersebut, perlu dilakukan penelitian dengan tujuan mengetahui gambaran karakteristik depresi lansia di Panti Sosial.

\section{METODE}

Penelitian ini menggunakan desain penelitian cross sectional yang terdiri dari 135 lansia yang dipilih melalui purposive sampling di Panti Sosial Tresna Werdha Yogyakarta. Penelitian dilakukan pada bulan Maret 2020. Kriteria inklusi penentuan sampel adalah lansia yang berusia 60 tahun keatas, lansia yang telah menghuni panti selama lebih dari 6 bulan dan tidak memiliki keluarga.

Lansia diminta untuk mengisi instrumen Beck Depression Inventory (BDI) untuk mengetahui tingkat depresi yang dimiliki selama berada di dalam panti. Uji validitas dan reabilitas telah dilakukan pada instrumen BDI dan telah dinyatakan valid dan reliabel dengan nilai Alpha Cronbach sebesar 0,743 (Supriani, 2011). Uji etik penelitian dilakukan ke Komite Etik Departemen Keperawatan Fakultas Kedokteran Universitas Diponegoro dan dinyatakan lulus uji dengan nomor 79/EC/KEPK/D.Kep/II/2020. Data yang didapatkan dianalisis menggunakan analisa univariat untuk melihat gambaran tingkat depresi lansia. Data disajikan dalam bentuk tabel distribusi frekuensi berupa presentase (\%). 


\section{HASIL}

Hasil penelitian yang didapatkan berupa data deskriptif tentang usia, jenis kelamin, pendidikan, status pernikahan dan gambaran tentang tingkat depresi pada lansia, digambarkan pada tabel 1, sebagai berikut:

Tabel 1.

Gambaran Karakteristik Lansia di Panti Sosial $(\mathrm{n}=135)$

\begin{tabular}{|c|c|c|c|}
\hline Karakteristik & Subjek penelitian & $\mathrm{f}$ & $\%$ \\
\hline \multirow{5}{*}{ Usia } & $60-64$ & 34 & 25,2 \\
\hline & $65-69$ & 50 & 37,0 \\
\hline & $70-74$ & 21 & 15,6 \\
\hline & $75-79$ & 16 & 11,9 \\
\hline & 80 keatas & 14 & 10,3 \\
\hline \multirow{2}{*}{ Jenis kelamin } & Laki-laki & 73 & 54,1 \\
\hline & Perempuan & 62 & 45,9 \\
\hline \multirow{4}{*}{ Pendidikan } & Tidak sekolah & 28 & 20,8 \\
\hline & SD & 50 & 37,0 \\
\hline & SMP & 32 & 23,7 \\
\hline & SMA/SMK & 25 & 18,5 \\
\hline \multirow{3}{*}{ Status pernikahan } & Janda & 41 & 30,4 \\
\hline & Duda & 65 & 48,1 \\
\hline & Tidak menikah & 29 & 21,5 \\
\hline \multirow{4}{*}{ Tingkat depresi } & Tidak depresi & 38 & 28,1 \\
\hline & Depresi ringan & 55 & 40,7 \\
\hline & Depresi sedang & 27 & 20,1 \\
\hline & Depresi berat & 15 & 11,1 \\
\hline
\end{tabular}

Hasil studi karakteristik didapatkan bahwa usia lansia yang tinggal di Panti sosial terbanyak pada rentang usia 65-69 tahun $(37,0 \%)$, rentang usia lansia yang paling sedikit adalah lansia yang berusia 80 tahun keatas $(10,4 \%)$. Jenis kelamin lansia yang paling banyang tinggal di Panti Sosial adalah laki-laki yaitu sebanyak 73 lansia $(54,1 \%)$. Sebaran data pendidikan lansia yang tinggal di Panti Sosial paling banyak adalah SD sebanyak 50 lansia (37,0\%), sedangkan pendidikan yang paling sedikit adalah SMA/SMK sebanyak 25 lansia $(18,5 \%)$. Status pernikahan lansia yang ada di Panti Sosial terbanyak adalah duda yaitu sebanyak 65 lansia $(48,1 \%)$. Tingkat depresi pada lansia yang ada di Panti Sosial terbanyak adalah tingkat depresi ringan yaitu sebanyak 55 lansia $(40,7 \%)$

\section{PEMBAHASAN}

\section{Usia}

Hasil penelitian menunjukkan mayoritas lansia yang tinggal di Panti Sosial berada pada rentang usia 65-69 tahun yaitu sebanyak 50 lansia $(37,0 \%)$. Temuan ini sesuai dengan hasil penelitian menunjukkan bahwa prevalensi depresi meningkat sejalan dengan bertambahnya usia lansia (Lindia Prabhaswari, 2015). Seiring bertambahnya usia, maka akan terjadi peningkatan morbiditas, penurunan status fungsional, serta adanya paparan berbagai faktor risiko dan pengalaman hidup yang dapat mempengaruhi kejiwaan lansia, sehingga berisiko menempatkan lansia dalam keadaan depresi (Kartika, 2012).

\section{Jenis kelamin}

Lansia yang ada di Panti Sosial terbanyak adalah lansia yang berjenis kelamin laki-laki sebanyak 73 orang $(54,1 \%)$. Pada umumnya depresi pada lansia laki-laki sama dengan lansia perempuan, namun seringkali depresi pada laki-laki lebih sulit diketahui karena sejumlah lansia laki-laki yang tidak mencari atau menerima bantuan dan karena itu depresi pada mereka tetap tidak terdiagnosis dan tidak terobati (Octavianti, 2013). Penelitian lain mengatakan bahwa koping lansia perempuan lebih baik daripada lansia laki-laki dalam menghadapi masalah. Lansia perempuan sering menggunakan koping emotion focused (misalhnya dengan berkata pada diri sendiri karena mendapatkan masalah dan menangis) dan seeking support (misalnya mencari seseorang profesional untuk membantu menyelesaikan masalah, berdoa, berserah diri kepada Tuhan Yang Maha Esa) (Lindia Prabhaswari, 2015). Lansia perempuan lebih mampu mengeluarkan emosi dan perasaannya sehingga beban dan tekanan psikologii yang ada bisa berkurang. Berbeda dengan lansia laki-laki yang lebih banyak 
menggunakan stategi avoidance (misalnya makan lebih banyak daripada biasanya, merokok, dan lebih menarik diri). Strategi ini bisa mengalihkan masalah, namun tidak bisa menyelesaikan dan menghilangkan masalah tersebut. Hal ini menandakan lansia perempuan lebih baik dalam merespon masalah daripada lansia laki-laki (Sari, 2012).

\section{Pendidikan}

Ditinjau dari tingkat pendidikan, sebanyak 50 orang $(37,0 \%)$ lansia berpendidikan SD dan sebanyak 28 orang $(20,8)$ lansia yang tidak sekolah. Hal ini dapat memicu peningkatan kejadian depresi pada lansia. Temuan ini sesuai dengan hasil penelitian yang mengatakan bahwa proporsi depresi pada lansia yang berpendidikan rendah lebih besar dibandingkan proporsi depresi pada lansia berpendidikan sedang/menengah dan tinggi.(Lindia Prabhaswari, 2015) Pendidikan dapat mempengaruhi perilaku seseorang. Semakin tinggi pendidikan seseorang, maka akan semakin mudah menerima informasi sehingga semakin banyak pula pengetahuan yang dimiliki. disamping itu, pendidikan juga merupakan modal awal dalam perkembangan kognitif, dimana kognitif tersebut dapat menjadi mediator antara suatu kejadian dan mood, sehingga kurangnya pendidikan dapat menjadi faktor risiko lansia menderita depresi.(Livana PH, Yulia S, 2019)

\section{Status pernikahan}

Berkaitan dengan status pernikahan, proporsi lansia yang banyak mengalami depresi adalah lansia yang tidak memiliki pasangan. Hal ini sejalan dengan hasil penelitian yang didapatkan bahwa status pernikahan lansia yang ada di Panti Sosial adalah janda sebanyak 41 orang $(30,4 \%)$, duda sebanyak 65 orang $(48,1 \%)$ dan lansia yang tidak menikah sebanya 29 orang $(21,5 \%)$. Kondisi depresi akan lebih berat jika terjadi pada lansia yang tidak menikah. Hal ini didukung oleh penelitian sebelumnya yang menyatakan bahwa gangguan depresi mayor lebih sering dialami oleh individu yang bercerai atau lajang dibandingkan dengan yang menikah (Mahendra Dwi Darmawan, 2016). Seseorang yang berstatus duda/janda atau tidak menikah berisiko hidup sendiri, dimana hidup sendiri juga merupakan faktor risiko terjadinya depresi pada lansia (Sari, 2012). Lansia yang memiliki pasangan hidup akan memiliki tempat untuk saling berbagi dan mendukung dalam menghadapi masa tua sehingga risiko terkena depresi lebih rendah (Kartika, 2012).

\section{Tingkat depresi}

Mayoritas dari sampel penelitian lansia mengalami depresi ringan, angka tersebut dapat berubah jika lansia dengan depresi ringan tidak mendapatkan perawatan khusus untuk mengurai tingkat depresi yang dialami. Penelitian (Lindia Prabhaswari, 2015) mengungkapkan bahwa beragam faktor yang dapat menyebabkan kenaikan tingkat depresi lansia, diantaranya dukungan keluarga dan tempat tinggal. Salah satu faktor yang paling utama untuk mendasari terjadinya depresi, karena kehilangan merupakan suatu keadaan individu yang berpisah dengan suatu yang sebelumnya ada. Lansia yang tidak memiliki keluarga untuk menemani lansia dapat mengurangi kontribusi lansia dalam melakukan aktivitas sehingga rasa jenuh dan sepi yang dirasakan oleh lansia meningkat (Nailil, Arwani, 2013). Lansia yang baru menetap di panti cenderung membutuhkan adaptasi di tahun awal kehidupan di panti sehingga kurang interaksi antar lansia.Kehilangan keluarga atau orang yang disayangi merupakan pencetus timbulnya depresi. Responden merasa disakiti, diacuhkan oleh keluarga, dibuang oleh keluarga dan kurangnya perhatian dari keluarga (Maslim, 2013).

Seyogyanya masa tua yang dirasakan lansia seharusnya merasakan kasih sayang ditengah keluarga serta menikmati hasil jerih payah yang sepanjang hidupnya telah dicapai. Namun, kenyataan yang dihadapi lansia justru sebaliknya (Johana., 2014). Rasa sepi yang secara terus menerus dirasakan oleh lansia mengakibatkan beberapa dampak bagi kesehatan lansia baik secara fisik maupun psikologis. Keadaan tidak tertanganinya masalah kesepian pada lansia dapat memperparah tingkat depresi dan mengganggu kualitas hidup lansia itu sendiri. Hal tersebut diatas dibuktikan oleh penelitian bahwa lansia yang mengalami depresi sangat rentan terhadap masalah lain seperti meningkatkan tekanan darah .

\section{SIMPULAN}

Hasil penelitian disimpulkan bahwa lansia yang tinggal di Panti sosial terbanyak pada rentang usia 65-69 tahun, berjenis kelamin laki-laki, berpendidikan terakhir SD, berstatus duda. Tingkat depresi pada lansia yang ada di Panti Sosial mayoritas berada pada tingkat depresi ringan.

\section{DAFTAR PUSTAKA}

Anik Supriani (2011) Tingkat Depresi Lansia Ditinjau Dari Tipe Kepribadian Dan Dukungan Sosial [Surakarta]. Universitas Sebelas Maret. 
Azizah., L. M. (2011) Keperawatan Lanjut Usia. 1st edn. Yogyakarta: Graha Ilmu.

JA, K. H. S. B. G. (2010) Sinopsis Psikiatri: Ilmu pengetahuan Perilaku Psikiatri Klinis. 1st edn. Jakarta: Bina Rupa Aksara.

Johana. (2014) 'Aspek Sosio-Psikologis Usia Lanjut Di Indonesia. Buletin Penelitian Kesehatan', Fakultas Psikologi Universitas Gajah Mada, No. 21 (4).

Kartika, S. (2012) 'Gambaran tingkat depresi pada lanjut usia (lansia) di panti sosial tresna wredha budi mulia 01 dan 03 Jakarta Timur', Universitas Indonesia., pp. 2012:174.

Kemenkes RI (2018) 'Hasil Utama Riskesdas 2018', Kemenkes RI: Badan Penelitian dan Pengembangan Kesehatan.

Lindia Prabhaswari, N. L. P. A. (2015) 'Gambaran kejadian depresi pada lanjut usia di wilayah kerja Puskesmas Petang I Kabupaten Badung Bali', Program Studi Pendidikan Dokter, Fakultas Kedokteran Universitas Udayana, 7 No. 1(ISSN: 20899084).

Livana, P. H., Susanti, Y., Darwati, L. E., \& Anggraeni, R. (2018). Gambaran Tingkat Depresi Lansia. Nurscope. Jurnal Keperawatan Pemikiran Ilmiah,4(4), 8093.

http://jurnal.unissula.ac.id/index.php/jnm/ar ticle/view/3936.

Mahendra Dwi Darmawan (2016) 'Gambaran tingkat depresi pada lansia yang tinggal di Panti Griya Sehat Bahagia [Karanganyar]', Naskah Publikasi UMS, Vol.19(2), pp. 111. doi: 10.1017/S10416102.

Maslim, R. (2013) Buku Saku Diagnosisi Gangguan Jiwa Rujukan Ringks dari PPDGJIII dan DSM-5. Jakarta.: Ilmu Kedokteran Jiwa FK Unika Atmaja.

Nailil, Arwani, \& P. (2013) 'Hubungan antara karakteristik dengan kejadian depresi pada lansia di panti werda pelkris pengayoman [Semarang]', Stikes Telogorejo, Vol 2, pp. 1-9.

Octavianti, M. M. (2013) 'Gambaran Depresi Pada Lanjut Usia Di Panti Sosial Tresna
Werdha Mulia Dharma Kabupaten Kubu Raya Tahun 2012', Jurnal Mahasiswa PSPD FK Universitas Tanjungpura, 1(1).

Pae, K. (2017) 'Perbedaan tingkat depresi pada lansia yang tinggal di Panti Werdha dan yang tinggal di rumah bersama keluarga [Surabaya]', Jurnal Ners LENTERA, Vol 5 No 1, pp. 21-32.

Sari, K. (2012) Gambaran tingkat depresi pada lanjut usia (lansia) di Panti Sosial Tresna Werdha Budi Mulia 01 dan 03 [Jakarta Timur]. Universitas Indonesia. doi: 10.7454/jki.v19i2.464.

Suardiman (2011) Psikologi Usia Lanjut. Yogyakarta. 
Jurnal Keperawatan Jiwa Volume 8 No 2 Hal 117 - 122, Mei 2020

FIKKes Universitas Muhammadiyah Semarang bekerjasama dengan PPNI Jawa Tengah 